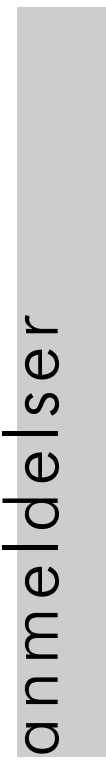

ladende rent filosofiske kommentarer i Filosofiske Undersøgelser. Overgangsfasen er heldigvis begyndt at få mere opmærksomhed og med udgivelsen af både Wiener-udgaven og Bergen-udgaven af Wittgensteins efterladte skrifter bliver den også mere tilgængelig. Men materialet er så omfattende og Wittgensteins diskussion ofte så specialiseret og indforstået, at man har brug for en guide.

For den almindelige læser kan Wittgenstein, Finitism, and the Foundations of Mathematics nok synes en stor mundfuld. Det er ikke en introduktion hverken til Wittgenstein eller matematikfilosofi. Men for enhver der ønsker at beskæftige sig seriøst med Wittgenstein, er Marions bog den bedste guide til matematikfilosofien i overgangsperioden. For matematikhistorikere vil den være interessant, fordi vi her får sat Wittgenstein ordentligt ind i en matematikhistorisk og -filosofisk sammenhæng. I den forbindelse behøver han ikke længere at optræde i rollen som den sære filosof, som ingen alligevel tog alvorligt. Marions diskussion af eksempelvis Kroneckerianerne Baire, Borel, Lebesgue og Skolems finitisme, og sammenligningerne mellem Ramsey, Brouwer, Weyl og Wittgenstein er fascinerende og lærerige. Det er en spændende og uhyre kompetent fortalt historie. Imidlertid foregår meget af det filosofiske drama i de tekniske detaljer. Vi kan derfor ikke undgå dem, hverken som historikere eller filosoffer. Det gør det også til krævende læsning. Men der er ingen vej udenom. Wittgenstein var en krævende tænker.

Peter C. Kjærgaard

\section{Taktens lov}

Jacques Derrida, Le toucher, Jean-Luc Nancy, Galilée, Paris 2000, 348 sider, 265 FF.

Jacques Derridas bog Le toucher, JeanLuc Nancy er et forsøg på at fremlæse følesansen (le toucher) som den centrale kategori i Jean-Luc Nancys filosofiske forfatterskab. Derrida tematiserer følesansen som "den bedste ledetråd" til en læsning af Nancy i dag. Dette er dog ikke bogens eneste ærinde, eftersom Derrida ligeledes ønsker at røre Nancy. Det drejer sig om at røre ham (le toucher) igennem en analyse af følesansen (le toucher) i hans værk. Dette spil mellem substantiv og verbum, mellem bestemt artikel og pronomen gennemsyrer hele bogen, der således forsøger at gøre sig fortjent til sin dobbelttydige titel: Følesansen, JeanLuc Nancy eller Røre ham, Jean-Luc Nancy.

Berøringen skal imidlertid foregå med takt, hvor taktens lov byder, at "det er nødvendigt at røre uden at røre" (81). Bogens fundamentale paradoks kan derfor formuleres på følgende måde: hvordan røre dig, JeanLuc Nancy, uden at jeg, Jacques Derrida, rører dig? Paradokset søges overvundet ved at røre Nancy ad omveje, hvorfor der gennemføres en analyse af følesansens filosofiske tematisering fra Aristoteles via Berkeley, Maine de Biran og Husserl til Didier Franck og JeanLouis Chrétien, for nu at nævne nogle af de centrale skikkelser i bogen.

Skønt Derrida mener, at bruddet med traditionen ikke kan være absolut på grund af den sproglige arv, 
tjener inddragelsen af andre filosoffer endvidere til at belyse Nancys originalitet, idet han, "den største tænker af følesansen nogensinde" (14), formår at ændre forestillingen om følesansen. Følesansen har altid været opfattet som værende forbundet med kontinuitet og umiddelbarhed, hvorfor den har nydt et absolut privilegium - $\mathrm{i}$ det mindste fra Aristoteles til Husserl. Ifølge Derrida fortsætter kontinuitetstanken dog helt op til i dag, hvor den bl.a. lader sig finde i det privilegium, det haptiske nyder hos Deleuze og Guattari i Mille Plateaux (jf. en bliven-haptisk af det optiske). Overfor dette postulat om kontinuitet, placerer Derrida med slet skjult præference Nancys analyser, der påpeger, hvorledes det haptiske eller taktile altid allerede er betinget af et brud: "kontinuiteten er aldrig givet. Der er aldrig en ren og umiddelbar erfaring af kontinuitet" (144),.

Nancys refleksioner vedrørende følesansen - og i forlængelse heraf kroppen - er karakteriserede ved, at han inddrager teknikken i sine overvejelser. Ifølge Nancy er et "jeg" ikke isoleret og uafhængigt af teknikken, som den optræder i samtiden. Den personlige kontingens er krydset med den tekniske udviklings kontingens. Anderledes formuleret er jeg'et altid betinget eller påvirket af noget andet end det selv. Det ydre er altid allerede i det indre, også når det drejer sig om noget så intimt som ens eget selv, hvilket derfor ikke er så intimt eller isoleret, som man måske ofte forestiller sig. Hermed brydes der ligeledes med Husserl og den fænomenologiske tradition, hvor følesansen finder sin begyndelse i en solipsistisk sfære.

En af Nancys kvaliteter består kort sagt $i$ at fremhæve, hvorledes tematiseringen af følesansen må være opmærksom på det brud, der altid allerede betinger berøringen. Dette overser de andre filosoffer, da de ikke tager højde for teknikken. Idet Nancy viser, hvorledes følesansen er betinget af teknikkens mulige indtrængen, påpeger han, at forestillingen om følesansen må reevalueres. Han stiller sig med andre ord skeptisk overfor, at følesansen som sådan skulle være givet: "følesansen gives ikke, der er ikke nogen oprindelig eller væsentlig oprindelig følesans før den tekniske protese, før dens [den tekniske proteses] nødvendige mulighed" (252). Dette citat må ikke misforstås. Derrida hævder ikke, at Nancy forkaster følesansen fuldstændigt. Der gøres ikke op med tilstedeværelsen af en følesans. Derimod gøres der op med forestillingen om en ubetinget følesans, der opretholder et oprindeligt nærvær. Det rene nærvær afsløres som en illusion, og følesansen fremstilles som konstitueret. Hermed tilbagevises endvidere den traditionelle strukturering af sanserne, hvor følesansen er prioriteret $\mathrm{i}$ kraft af dens formodede evne til at opretholde en oprindelig kontinuitet. To pointer følger således af Derridas læsning af følesansen hos Nancy: berøringen er betinget af et brud, hvorfor følesansen ikke opretholder en oprindelig kontinuitet; det er nødvendigt med en omstrukturering af sanserne, der bryder med den traditionelle prioritering af følesansen.

Det synes ubetvivleligt, at Le toucher, Jean-Luc Nancy vil være med 
til at bestemme megen fremtidig læsning af Nancy. Allerede af den grund at teksten er den første boglange studie, der vier sig Nancys endnu relativt ukendte værk. Bogen må dog ikke forveksles med det, den indledningsvist giver sig ud for at være, nemlig en "beskeden introduktion" til Nancy værk. Den giver hverken en overordnet introduktion til Nancys værk eller en mere detaljeret introduktion til enkelte af værkerne. I det mindste ikke hvis man forstår introduktion som en "beskeden" fremlægning af et værks eksplicitte teser.

En af bogens styrker er snarere dens originale åbning af Nancys tekster via fremlæsningen af en marginal figur, "le toucher", som omdrejningspunktet for Nancys værk. Skønt Derrida primært læser Nancys tidlige tekster, da bogen er en genskrivning af en artikel allerede skrevet og trykt $i$ 1992, synes analysen også at gælde for Nancys seneste tekster, hvor begrebets betydning ikke er blevet mindre. Ikke desto mindre kan man stille sig skeptisk overfor udsagnet, at Le toucher, Jean-Luc Nancy følger "den bedste ledetråd" til en læsning af Nancys værk i dag, idet denne læsning bl.a. medfører en reduktion eller ignorering af fællesskabstanken, der eksplicit har udfoldet sig som et centralt punkt i Nancys tekster de seneste to årtier.

Ligeledes synes en anden af bogens styrker på samme tid at udgøre bogens svage - eller rettere irriterende - moment. Idet Derrida bogen igennem forsøger at røre Nancy, og røre ham med takt, dvs. uden at rore, tilføjer han tematiseringen af følesansen et performativt aspekt, således at skellet mellem form og indhold ikke kan opretholdes. Det irriterende er imidlertid, at den tematiserede berøring uden berøring - skønt nok så nødvendig - forbliver umulig i praksis. Tekstens forsøg på at sammenpasse form og indhold må således på grund af indholdet nødvendigvis blive en ujævn og til tider frustrerende oplevelse for læseren, hvilket Derrida ikke er uvidende om. Hvorvidt bogen opfattes som genial eller unødvendigt vanskelig afhænger derfor mindre af pointerne i bogen end af læserens temperament. Uanset temperament synes det dog fornuftigt for nye Nancy interesserede $i$ første omgang at læse Nancy selv, frem for at læse Derridas bog som den introduktion den aldrig rigtig bliver, og så læse Le toucher, Jean-Luc Nancy senere, når man har behov for og lyst til en udfordrende læsning af Nancys forfatterskab.

Jesper Lohmann

\section{Barndommen}

Hugh Cunningham, Børn og barndom - i den vestlige verden efter 1500, oversat af Ib Høy Hansen, Forlaget Klim, 2000, 254 sider, $285 \mathrm{kr}$.

Phillip Ariès satte for alvor gang $i$ afsøgningen af barndommens historie i 1960 med bogen L'Enfant et la vie familiale sous l'Ancien Régime (dansk oversættelse i udvalg 1982 Barndommens historie). Han interesserede sig for forskydninger i ideen om fami- 